\title{
NOTES
}

\section{TRAFFIC STOPS, REASONABLE SUSPICION, AND THE COMMONWEALTH OF PENNSYLVANIA: A STATE CONSTITUTIONAL ANALYSIS}

Dennis J. Buffone*

\section{INTRODUCTION}

The Fourth Amendment to the Federal Constitution protects individuals against unreasonable searches and seizures. ${ }^{1}$ Traditionally, the Supreme Court has interpreted the Fourth Amendment to require warrants supported by probable cause in both the search and seizure contexts. In Terry v. Ohio, ${ }^{2}$ the Supreme Court recognized that not all interactions between police and citizens involve intrusions serious enough to trigger the full probable cause standard. ${ }^{3}$ As a result, the Court delineated a specific, narrowly applicable exception to the general rule. ${ }^{4}$ The Court held that in situations where the police have specific and articulable grounds that provide them with reasonable suspicion that criminal activity is afoot, they may briefly detain an individual for

\footnotetext{
* J.D. Candidate, 2008, University of Pittsburgh School of Law.

1. U.S. Const. amend. IV; see also Elkins v. United States, 364 U.S. 206, 222 (1960).

2. 392 U.S. 1 (1968).

3. See id. at 9 (" $[\mathrm{T}]$ he Constitution forbids ... not all searches and seizures, but unreasonable searches and seizures." (citing Elkins v. United States, 364 U.S. 206, 222 (1960)).

4. Id. at 30. The investigative detention standard enunciated in Terry is noteworthy in its entirety. The Court held that the police may conduct such a detention only "where a police officer observes unusual conduct which leads him reasonably to conclude in light of his experience that criminal activity may be afoot and that the persons with whom he is dealing may be armed and presently dangerous." Id.
} 
purposes of investigation. ${ }^{5}$ Both the facts of Terry and the language of Justice Warren's opinion leave no doubt that the exception was to be construed and applied in only the narrowest of contexts. ${ }^{6}$ However, as lower courts interpreted and applied Terry in the following years, the standard enunciated in Terry blurred considerably. Hence came the development of the wellentrenched, but nebulous, investigative detention doctrine.

In 1983, the Pennsylvania Legislature enacted title 75, section 6308(b) of the Pennsylvania Code to provide police officers with a standard for the level of suspicion necessary to stop a vehicle to enforce the Pennsylvania Vehicle Code. The provision, before a recent amendment, provided in pertinent part:

\begin{abstract}
Authority of Police Officer.-Whenever a police officer ... has articulable and reasonable grounds to suspect a violation of this title, he may stop a vehicle, upon request or signal, for the purpose of checking the vehicle's registration, proof of financial responsibility, vehicle identification number or engine number or driver's license, or to secure such other information as the officer may reasonably believe to be necessary to enforce the provisions of this title. ${ }^{7}$
\end{abstract}

Confusion permeated the courts of Pennsylvania at all levels as to the meaning of the phrase "reasonable and articulable grounds to suspect" in the statute. Because this language is not the mirror image of either the reasonable suspicion or probable cause standards set forth by the United States Supreme Court, Pennsylvania courts' interpretations were inconsistent and unclear. Finally, in Commonwealth v. Whitmyer, ${ }^{8}$ the Supreme Court of Pennsylvania settled the matter, at least temporarily. ${ }^{9}$ The court concluded that the words in the statute required nothing more or less than probable cause, and the semantic disparity between the two phrases was "nothing more than a distinction without a difference." 10

5. Id. It should be noted here that this is only the first of a multi-tiered scheme that the Court developed to govern each progressive step of the entire police-citizen interaction. I am dealing here only with the first - the initial - investigative stop.

6. Regarding the specific facts giving rise to the exception, Justice Warren noted, "[W]e deal here with an entire rubric of police conduct-necessarily swift action predicated upon the on-the-spot observations of the officer on the beat." Id. at 20 (emphasis added).

7. 75 Pa. Cons. STAT. $\S 6308$ (b) (1983) (second emphasis added). The provision makes no distinction between different sections of the Motor Vehicle Code. Thus, the authority granted here applies to police officers' conduct in situations where they make a stop for a speeding violation and, alternatively, where they suspect that a motorist is driving under the influence of alcohol.

8. $\quad 668$ A.2d 1113 (Pa. 1995)

9. Id. at 1116 .

10. Id. 
Following a subsequent line of decisions by the Superior Court of Pennsylvania, it appeared as if that court was requiring a level of suspicion lower than that announced in the United States Supreme Court's original traffic stop cases and in Whitmyer itself. ${ }^{11}$ The Supreme Court of Pennsylvania, in response, decided Commonwealth $v$. Gleason, ${ }^{12}$ holding that the probable cause standard was the only standard to be applied in traffic stop situations, and that the superior court had mistakenly lowered the standard in their previous application of the statutory language..$^{13}$ It seemed as if the court in Gleason had finally laid to rest any uncertainties about the suspicion required to make a valid traffic stop. Then, in 2004, the Pennsylvania Legislature, in a move no doubt in response to the court's decision in Gleason, revised section 6308(b) to read as follows:

(b) Authority of Police Officer.-Whenever a police officer is engaged in a systematic program of checking vehicles or drivers or has reasonable suspicion that a violation of this title is occurring or has occurred, he may stop a vehicle, upon request or signal, for the purpose of checking the vehicle's registration, proof of financial responsibility, vehicle identification number or engine number or the driver's license, or to secure such other information as the officer may reasonably believe to be necessary to enforce the provisions of this title. ${ }^{14}$

The legislature's intent here is clear-to lower the standard. ${ }^{15}$ The Supreme Court of Pennsylvania has not yet granted allocatur to an appeal regarding the constitutionality of this change. The Pennsylvania Superior Court has to this point upheld the statutory provision against constitutional attacks regarding the application of the provision in Driving Under the Influence (DUI) situations. ${ }^{16}$ Although the issue has been presented, the superior court has not addressed the constitutionality of its application to routine traffic stops that

11. For a list and analysis of these cases, see supra Part B(3).

12. 785 A.2d 983 (Pa. 2001).

13. Id. at 985 n.1.

14. 75 Pa. Cons. Stat. Ann. § 6308(b) (West 2004) (emphasis added).

15. The intention has very recently been wholly endorsed by the Pennsylvania Superior Court. See Commonwealth v. Smith, 917 A.2d 848, 850 (Pa. Super. Ct. 2007). The court in Smith cited Justice Eakin's concurring opinion in Martin v. Commonwealth, 905 A.2d 438 (Pa. 2006), in support of its endorsement of the legislative intent of the amendment. Smith, 917 A.2d at 850. Notably, Justice Eakin's concurrence merely recognized the alteration made by the legislature. Martin, 905 A.2d at 449-50. Because the constitutionality of the change was not before the court, it did not decide upon its validity. Id. at $450 \mathrm{n} .1$.

16. See Commonwealth v. Sands, 887 A.2d 261, 271-72 (Pa. Super. Ct. 2005) ("We hold that the limited intrusion permitted by Section 6308(b) in the case of a vehicular stop based upon a reasonable suspicion that the driver is driving under the influence, as balanced against the Commonwealth's salutary interest in preventing DUI violations, violates neither the Fourth Amendment nor Article I, Section 8."). 
are not DUI-related. ${ }^{17}$ Doubt has loomed, however. In Commonwealth v. Anderson, ${ }^{18}$ Superior Court Judge Gantman, in a combination concurring and dissenting opinion, noted that although the question was not before her, the change in the statutory standard was certainly questionable. ${ }^{19}$

Since neither the Superior Court nor the Supreme Court of Pennsylvania has addressed the constitutionality of section 6308(b), particularly regarding routine, non-DUI-based traffic stops, this Note does just that. However, the scope of this Note extends only to section 6308(b) and its validity under the Pennsylvania Constitution. No arguments here rest on the Federal Constitution, and any mention of or analogy thereto are only for purposes of persuasive comparison. The Supreme Court of Pennsylvania, when the issue has been properly preserved before it, has taken the opportunity on a few rare but increasingly common occasions to interpret the provisions of the state constitution independently from its federal counterpart. Conveniently, three of the seminal cases where it has done so all involved article I, section 8. This provision is Pennsylvania's analogue to the Fourth Amendment of the Federal Constitution, protecting citizens against unreasonable searches and seizures. Not only are the two provisions different in language, but as the state supreme court has noted, they have different meanings, histories, and purposes. ${ }^{20}$

In Commonwealth v. Edmunds, ${ }^{21}$ the Pennsylvania Supreme Court for the first time developed a framework for independent analysis under the Pennsylvania Constitution. ${ }^{22}$ In this Note, I use that framework to argue the

17. See Commonwealth v. Little, 903 A.2d 1269, 1272-73 (Pa. Super. Ct. 2006). The superior court denied review of the constitutional issue presented by the appellant in the case because it was not properly preserved at trial. It finally concluded: "Moreover, appellate review of an order denying suppression is limited to examination of the precise basis under which suppression initially was sought; no new theories of relief may be considered on appeal." Id. (citations omitted).

18. 889 A.2d 596 (Pa. Super. Ct. 2005).

19. Id. at 601-02. Judge Gantman noted, "Our Supreme Court in Whitmyer and later in Gleason referenced Prouse directly in their discussion of probable cause as the appropriate standard for vehicle stops. As such, the propriety of the legislative revision is subject to some debate." Id. at 602 (referring to Delaware v. Prouse, 440 U.S. 648 (1979)). However, Judge Gantman also noted that the act giving rise to the controversy before her happened prior to the revision of the statute, and so the constitutionality of the amendment was not at issue. Id.; see also Commonwealth v. Ulman, 902 A.2d 514, 517 n.3 (Pa. Super. Ct. 2006) (mirroring Judge Gantman's reluctance and again not addressing the constitutional issue because it was not directly before the court).

20. See supra Part B.

21. 586 A.2d 887 (Pa. 1991).

22. Id. at 895. The court's framework in Edmunds came in response to the United States Supreme Court's requirement that state courts make a plain statement of the "adequate and independent state grounds upon which [they] rely, in order to avoid any doubt that [they] have rested [their] decision squarely upon [state] jurisprudence.” Id. (citing Michigan v. Long, 463 U.S. 1032 (1983)). 
following: (1) article I, section 8 of the state constitution affords more protection against unreasonable searches and seizures than does its federal counterpart; (2) in interpreting article I, section 8, the Supreme Court of Pennsylvania has consistently required probable cause for routine traffic stops; (3) the requirement is based exclusively on state constitutional law (as opposed to statutory interpretation); (4) article I, section 8 of the state constitution affords even more protection than that which would be required to invalidate the reasonable suspicion standard; ${ }^{23}$ and (5) numerous public policy considerations in the commonwealth support the retention of the probable cause standard. In sum, the Pennsylvania Constitution forbids any level of suspicion lower than traditional probable cause for traffic stops, and the state legislature's amendment of the standard was an unconstitutional legislative action. ${ }^{24}$

\section{The EDMUndS Framework}

In Edmunds, the court set out its own plan for how independent analysis based on the state constitution should proceed. To understand the case's framework, the substance of the holding, and the commentary on the Pennsylvania Constitution, an overview of some detail is necessary. First, the issue presented to the court was "whether Pennsylvania should adopt the 'good faith' exception to the exclusionary rule as articulated by the United States Supreme Court in the case of United States v. Leon." ${ }^{25}$ Ultimately, the state supreme court held that "a 'good faith' exception to the exclusionary rule would frustrate the guarantees embodied in Article I, Section 8, of the

23. At least three cases are on point here: The Edmunds case itself, Commonwealth v. Matos, 672 A.2d 769 (Pa. 1996), and Commonwealth v. Rodriquez, 614 A.2d 1378 (Pa. 1992). These cases will be discussed at length later in this Note. It is noteworthy that in two of these cases, Edmunds and Rodriquez, the Supreme Court of Pennsylvania found that the standards adopted by the United States Supreme Court were in direct conflict with article 1 , section 8 of the Pennsylvania Constitution. In both cases, the federal standard was superseded by a more stringent state standard.

24. I am specifically not addressing the reasonable suspicion standard here as applied to DUI situations. Those instances arguably present a different issue.

25. Edmunds, 586 A.2d at 888 . The court also framed the question a second time as "whether the federal Leon test circumvents the acknowledged deficiencies under Pennsylvania law, and prevents the suppression of evidence seized pursuant to an invalid search warrant." Id. at 891-92. Since the superior court below expressly relied on and incorporated Leon into its opinion, the supreme court had no choice but to address it head-on. United States v. Leon, 468 U.S. 897 (1984), concerned the constitutionality of a warrant lacking probable cause on its face. The Supreme Court of Pennsylvania has interpreted Leon to hold that "the [Fourth] Amendment does not mandate suppression of illegally seized evidence obtained pursuant to a constitutionally defective warrant, so long as the police officer acted in good faith reliance upon the warrant issued by a neutral and detached magistrate." Edmunds, 586 A.2d at 892. 
Pennsylvania Constitution." ${ }^{26}$ From the outset, and without much hesitation, one can conclude from the language of the court's opinion that article I, section 8 must "embody" some "guarantees" that the Federal Constitution does not. Furthermore, the court in Edmunds emphasized that state high courts "are not bound by the decisions of the United States Supreme Court which interpret similar (yet distinct) federal constitutional provisions," and that the federal standard is only a floor below which state courts cannot go. ${ }^{27}$ Independent analysis is both permitted and encouraged. ${ }^{28}$

In its "plain statement" of the four factors to be weighed in the analysis, the court set out the following for consideration:

(1) text of the Pennsylvania constitutional provision;

(2) history of the provision, including Pennsylvania case-law;

(3) related case-law from other states;

(4) policy considerations, including unique issues of state and local concern, and applicability within modern Pennsylvania jurisprudence. ${ }^{29}$

The court also noted that federal precedent is not totally irrelevant and can be useful in guiding the analysis. ${ }^{30}$

\section{AnAlysis}

\section{A. The Text}

A textual comparison of article I, section 8 of the Pennsylvania Constitution and the Fourth Amendment to the Federal Constitution does not provide much insight into their possible differences. The text of section 8 provides:

$\S 8$. Security from searches and seizures

The people shall be secure in their persons, houses, papers and possessions from unreasonable searches and seizures, and no warrant to search any place or to seize any person or things shall issue without describing them as nearly as may be, nor

\footnotetext{
26. Edmunds, 586 A.2d at 888.

27. Id. at 894 (citations omitted).

28. See Prune Yard Shopping Ctr. v. Robins, 447 U.S. 74, 80-81 (1980).

29. Edmunds, 586 A.2d at 895 . The court here went into a short discussion of the "New Federalism" that lately has gained prominence in state court jurisprudence. State high courts are more and more undertaking their own constitutional analysis of many of the analogous federal questions going before the United States Supreme Court. Id. at 895 n.6.

30. Id. at 895 . From time to time, I will allude to United States Supreme Court precedent in my analysis. It is, of course, utilized here only as a means of comparison.
} 
without probable cause, supported by oath or affirmation subscribed to by the affiant. $^{31}$

The text of the Fourth Amendment reads:

The right of the people to be secure in their persons, houses, papers, and effects, against unreasonable searches and seizures, shall not be violated, and no Warrants shall issue, but upon probable cause, supported by Oath or affirmation, and particularly describing the place to be searched, and the persons or things to be seized. $^{32}$

At first blush, the two provisions seem rather similar, even identical, in nature, text, and purpose. However, the state supreme court has time and again reiterated that the textual similarity between the two provisions does not bind the court to making identical interpretations of each. ${ }^{33}$ This is an important premise. Other states that have interpreted their own constitutional provisions to afford the same protections as the Fourth Amendment do, at the outset, claim that the identical language between the two is of conclusive significance. ${ }^{34}$ The Pennsylvania Supreme Court, however, has flatly rejected this proposition. ${ }^{35}$ An examination of the differences in the history and purpose between the two provisions reveals much difference indeed.

\section{B. History}

\section{The Language}

The court in Edmunds underwent an extensive analysis of the history of article I, section 8. It noted that the provision is a decade older than its federal counterpart and has its origins in the original state constitution of $1776 .{ }^{36}$

\footnotetext{
31. PA. Const. art. I, $\S 8$.
}

32. U.S. CONST. amend. IV. 1987)).

33. Edmunds, 586 A.2d at 895-96 (citing Commonwealth v. Tarbert, 535 A.2d 1035, 1038 (Pa.

34. See, e.g., People v. Robinson, 767 N.E.2d 638, 642 (N.Y. 2001). The court concluded that the similarity between New York's provision and the analogous federal provision was determinative in holding that the two afforded similar protections. Interestingly, the court in Robinson was addressing Whren $v$. United States, 517 U.S. 806 (1996), and the validity of pretextual traffic stops. Like Whren, the Robinson court held pretext to be of no significance in the validity of the stop, as long as probable cause was present at the outset. Robinson, 767 N.E.2d at 638 .

35. Commonwealth v. Matos, 672 A.2d 769, 772 (Pa. 1996) (citing Edwards, 586 A.2d at 896).

36. Edmunds, 586 A.2d at 896 ("The Pennsylvania Constitution was therefore meant to reduce to writing a deep history of unwritten legal and moral codes which had guided the colonists from the beginning of William Penn's charter in 1681. Unlike the Bill of Rights of the United States Constitution 
Examining the language of the original provision, it is clear that the idea of a requirement of particularized suspicion for issuing warrants was contemplated in 1776 upon the ratification of the document. ${ }^{37}$ This all came well before the Framers of the Fourth Amendment endeavored to set down on paper the protections in that provision. ${ }^{38}$ The Edmunds court came to this very conclusion, stating that "at the time the Pennsylvania Constitution was drafted in 1776, the issue of searches and seizures unsupported by probable cause was of utmost concern to the constitutional draftsmen." ${ }^{39}$ Hence, the probable cause standard developed in Pennsylvania, even more so than in states whose constitutions post-dated the Federal Constitution, has a scope and purpose uniquely independent from the Fourth Amendment.

\section{The Purpose}

The state prohibition against unreasonable searches and seizures is remarkably different than the federal prohibition. The United States Supreme Court has made it clear that the primary purpose of the Fourth Amendment is to deter police misconduct. ${ }^{40}$ Thus, the federal exclusionary rule, by which illegally seized evidence is kept outside the purview of a jury, operates as a mechanism to enforce fundamental constitutional rights - it is a remedy. ${ }^{41}$

\footnotetext{
... the Declaration of Rights in the Pennsylvania Constitution was an organic part of the state's original constitution of $1776 \ldots$..." (citation omitted)).

37. PA. Const. of 1776, cl. X. The text of Clause 10 of the original constitution of 1776 provides: That the people have a right to hold themselves, their houses, papers and possessions free from search and seizure; and therefore warrants, without oaths or affirmations first made, affording a sufficient foundation for them, and ... not particularly described, are contrary to Id. that right, and ought not be granted.

38. Edmunds, 586 A.2d at 896 (citing Willi Paul Adams, The First American Constitutions 61 (1980)); see also Commonwealth v. Sell, 470 A.2d 457, 467 (Pa. 1983). In interpreting the state constitution, the court in Sell concluded that "[i]n construing Article I, section 8, we find it highly significant that the language employed in that provision does not vary in any significant respect from the words of its counterpart in our first constitution. The text of Article I, section 8 thus provides no basis for the conclusion that the philosophy and purpose it embodies today differs from those which first prompted the Commonwealth to guarantee protection from unreasonable governmental intrusion." Id.

39. Edmunds, 586 A.2d at 897.

40. See United States v. Leon, 468 U.S. 897, 916 (1984); Weeks v. United States, 232 U.S. 383, 391-93 (1914). A second purpose that has been posited by the Supreme Court is "judicial integrity." Elkins v. United States, 364 U.S. 206, 222 (1960). The Court in Terry emphasized that "[c]ourts which sit under our Constitution cannot and will not be made party to lawless invasions of the constitutional rights of citizens by permitting unhindered governmental use of the fruits of such invasions.” Terry v. Ohio, 392 U.S. 1, 13 (1968).

41. See Potter Stewart, The Road to Mapp v. Ohio and Beyond: The Origins, Development, and
} 
Article I, section 8 of the Pennsylvania Constitution, however, has a significantly different purpose. The right to privacy, unlike that at the federal level, has existed in Pennsylvania since time out of mind. The court in Edmunds noted that article I, section 8 is "meant to embody a strong notion of privacy, carefully safeguarded in this Commonwealth for the past two centuries. ${ }^{42}$ In Commonwealth $v$. Sell ${ }^{43}$ the court, again construing article I, section 8 , concluded that

\begin{abstract}
the survival of the language now employed in article I, section 8 through over 200 years of profound change in other areas demonstrates that the paramount concern for privacy first adopted as a part of our organic law in 1776 continues to enjoy the mandate of the people of this Commonwealth. ${ }^{44}$
\end{abstract}

Thus the central theme of the provision is privacy, not deterring police misconduct. A long line of cases starting in the 1970s clearly conclude that "Article I, Section 8 is unshakably linked to a right of privacy in this Commonwealth." 45 Most recently, the state supreme court in Commonwealth v. Melilli" ${ }^{46}$ concluded that "Article 1, [Section] 8 of the Pennsylvania Constitution ... may be employed to guard individual privacy rights against unreasonable searches and seizures more zealously than the federal government does under the Constitution of the United States by serving as an independent source of supplemental rights. ${ }^{47}$ The thrust of the provision is

Future of the Exclusionary Rule in Search-and-Seizure Cases, 83 Colum. L. Rev. 1365, 1384 (1983). Retired Justice Potter Stewart concluded that as a matter of history, "the exclusion of unconstitutionally obtained evidence is not a constitutional right, but a constitutional remedy." Id.

42. Edmunds, 586 A.2d at 897.

43. 470 A.2d 457 (Pa. 1983).

44. Id. at 467. The Sell opinion is yet another example of a situation where, in conducting an independent analysis under the state constitution, the Supreme Court of Pennsylvania rejected a federal rule based on the Fourth Amendment. Id. at 468. This case, along with the substance of Edmunds and Matos will be more thoroughly distilled later in this Note.

45. Edmunds, 586 A.2d at 898 (citations omitted). In Commonwealth v. Melilli, 555 A.2d 1254 (Pa. 1987), the court outlined the twin aims of the provision: the safeguarding of privacy and the fundamental requirement that warrants shall only be issued upon probable cause.

46. 555 A.2d 1254 (Pa. 1987).

47. Id. at 1258 (emphasis added). In fact, in each seminal case where the court has interpreted article I, section 8 against the Fourth Amendment, it has found greater inherent protections. In several cases, the Supreme Court of Pennsylvania has refused to apply a federal constitutional doctrine because it was in direct conflict with the state constitutional provision. See, e.g., Edmunds, 586 A.2d 887 (Pa. 1991) (rejecting the federal "good faith" exception to the exclusionary rule); Commonwealth v. Matos, 672 A.2d 769 (Pa. 1996) (rejecting the Supreme Court's seizure analysis in California v. Hodari D., 499 U.S. 621 (1991)); Commonwealth v. Dejohn, 403 A.2d 1283 (Pa. 1979) (rejecting the Supreme Court's privacy analysis in United States v. Miller, 425 U.S. 435 (1976)). 
clear: It serves to protect the privacy interests of Pennsylvania citizens.

\section{The Case Law}

The Pennsylvania Supreme Court's interpretation of the probable cause standard began with Commonwealth v. Swanger. ${ }^{48}$ In Swanger, the defendant was arrested and convicted of burglary based upon evidence seized during a routine traffic stop by the police. ${ }^{49}$ The police officer had no level of suspicion to make the stop and testified that he "saw nothing unusual about the vehicle or the manner in which it was operated before he ordered the stop." 50 The court held the stop invalid, and all evidence derived therefrom was suppressed.$^{51}$ While Swanger involved a purely arbitrary stop made with no level of suspicion and involved only the Fourth Amendment, it is significant for several reasons. First, the court for the first time balanced the competing interests of the driver and the police during a traffic stop. Balancing these competing interests, the court concluded that the individual's right to be free from unreasonable governmental intrusions outweighed the ability of the government to stop automobiles at random to ensure public safety. ${ }^{52}$ Second, a prime concern of the court was that police officers not be given "unreviewable discretion and authority to intrude into an individual's life for no cause whatsoever." 53 Third, and most important, was the specific rule set out in Swanger. The court held that "before a police officer may stop a single vehicle to determine whether or not the vehicle is being operated in compliance with the Motor Vehicle Code, he must have probable cause based on specific facts which indicate to him either the vehicle or the driver are in violation of the code. ${ }^{.54}$

Two important contextual points should be noted about the holding in Swanger. First, the Commonwealth's argument was largely based on a statutory provision in the Motor Vehicle Code granting police officers

48. 307 A.2d 875 (Pa. 1973).

49. Id. at 876-77.

50. Id. at 877 .

51. Id. at 879 .

52. Id. at 878. Despite the fact that the Commonwealth argued that the "automobile is a dangerous instrumentality, one of the nation's highest ranking causes of death, bodily injury and destruction of property," the court was not convinced that such an interest outweighed the importance of some level of suspicion. Id.

53. Id. If police had such discretion, the court noted, it could be used "arbitrarily, or as a guise for seeking evidence of other crimes, or on mere "fishing expeditions." Id. at 879.

54. Id. at 879 . 
seemingly unlimited discretion to stop automobiles for a number of purposes. ${ }^{55}$ The court's holding is not based in any part upon the statute, nor on its intended purpose. The analysis involves solely constitutional principles. Second, the decision came down in 1973, a full five years after the Terry decision and four years after the court incorporated the Terry standard into Pennsylvania law. ${ }^{56}$ The court was well aware of Terry's reasonable suspicion standard but did not rely on it, ${ }^{57}$ and for good reason. The court was likely not willing to make the logical leap required to connect the Terry standard with stopping an automobile for purposes of enforcing the Motor Vehicle Code. Different situations - it would seem-require different standards.

The next major case addressing the probable cause standard was Commonwealth v. Murray. ${ }^{58}$ In Murray, the defendant, while driving his automobile, was stopped by a police officer in connection with a burglary close by. ${ }^{59}$ As the police were following the vehicle, "no traffic laws were violated nor was there any indication of anything unusual either about the appearance of the vehicle or the behavior of its occupants." ${ }^{60}$ Evidence obtained from the stop led to the defendant's conviction. In reversing the decision of the superior court and granting the defendant's suppression motion, the Pennsylvania Supreme Court reiterated with considerable strength the standard set forth in Swanger only two years before. The court concluded:

It is thus certain that in this Commonwealth we will not permit the State under the guise of regulating the operation of motor vehicles upon the highway to single out vehicles for routine stops. . . If the alleged basis of a vehicular stop is to permit a determination whether there has been compliance with the Motor Vehicle Code of

55. 75 Pa. Stat. AnN. § 1221(b) (West 1973) (repealed 1976). The language of the statute read in pertinent part:

Any peace officer, who shall be in uniform, and shall exhibit his badge or other sign of authority, shall have the right to stop any vehicle, upon request or signal, for the purpose of inspecting the said vehicle, as to its equipment and operation ... and securing of such other information as may be necessary.

$I d$. Even though the language of the statute clearly intends to grant police very broad authority, the court here seems to have read into it the constitutional standard of probable cause.

56. See Commonwealth v. Hicks, 253 A.2d 276 (Pa. 1969).

57. Hicks was a case with facts strikingly similar to those in Terry. The defendant was stopped and patted down by police officers on a street in Philadelphia. Id. at 277. The court in Hicks concluded that the seizure was unconstitutional. Id. at 280 . The standard adopted was virtually the same as that in Terry - that "police must prove that specific conduct of the seized person, observed by them, justified and made reasonable their belief that criminal activity was afoot and that the seized person was armed and dangerous." Id. at 279.

58. 331 A.2d $414($ Pa. 1975)

59. Id. at 416

60. $I d$. 
this Commonwealth, it is encumbent upon the officer to articulate specific facts possessed by him, at the time of the questioned stop, which would provide probable cause to believe that the vehicle or the driver was in violation of some provision of the Code. ${ }^{61}$

The standard here is clear. When vehicle is stopped based upon a perceived violation of the Motor Vehicle Code, probable cause is the only sufficient level of suspicion.

Even more important in Murray, however, is the bifurcated analysis that the court performed between the probable cause and reasonable suspicion standards. It is here that we find the court first addressing Terry's investigative detention standard and how it applies in the automobile stop context. After analyzing the issue regarding the Motor Vehicle Code violation and concluding that probable cause was not present, the court turned to Terry. The court acknowledged that "[b]ecause a motorist's extreme mobility may otherwise allow him to avoid police confrontation, the State has an equally strong interest in these cases in stopping a moving vehicle to freeze momentarily a situation of suspected criminality." ${ }^{\prime 62}$ Under the Terry standard, the only evidence the Commonwealth proffered in support of reasonable suspicion was that the defendant, while parked in a driveway nearby the place of the burglary, assumedly left when he saw the police car. ${ }^{63}$ No evidence of a suspected violation of the Vehicle Code was offered in support of a finding of reasonable suspicion. ${ }^{64}$ This does not come as a surprise. The court made two very distinct analyses in the case. It applied the probable cause standard to stops for suspected violations of the Vehicle Code and the reasonable suspicion standard as set forth in Terry and Hicks to situations where other

61. Murray, 331 A.2d at 416-17 (footnote omitted) (citing Commonwealth v. Swanger, 307 A.2d 875, 879 (Pa. 1973); Commonwealth v. Boyer, 314 A.2d 317, 318 (1974)).

62. Id. at 418 .

63. Id. The court's language is telling of its view of the separate and distinct nature of the two situations presented by (1) suspected violations of the Motor Vehicle Code, and (2) suspected criminal activity in which the occupants of a vehicle have participated. Upon review of the Terry standard, the court stated that "[ $[\mathrm{t}] \mathrm{hus}$, it is also clear that an investigative stop of a moving vehicle to be valid must be based upon objective facts creating a reasonable suspicion that the detained motorist is presently involved in criminal activity." Id. (emphasis added). That criminal activity, as viewed by the court, does not logically include violations of the Motor Vehicle Code. Such violations are to be analyzed separately under the probable cause standard.

64. Id. at 417 ("Under the facts of the instant cause the record is barren of any evidence to suggest a basis for concluding that either the vehicle or its occupants were in any way in violation of the Code."). 
criminal activity was suspected.$^{65}$ Again, different standards apply to different situations. ${ }^{66}$

In the next seminal case, Commonwealth $v$. Whitmyer ${ }^{67}$ the court for the first time took the opportunity to address the legislature's 1983 enactment of title 75, section 6308(b) of the Pennsylvania Code, allowing for stops by police officers having "articulable and reasonable grounds to suspect a violation" of the Vehicle Code. ${ }^{68}$ In Whitmyer, the defendant crossed over the white line to pass another car, and was stopped by a police officer who apparently intended to cite him for driving at an unsafe speed. ${ }^{69}$ Upon approaching the defendant to issue the citation, the trooper observed the smell of marijuana, found the substance in defendant's coat pocket, and charged him with various possession offenses and driving at an unsafe speed. ${ }^{70}$ After the defendant's motion to suppress was granted by the trial court and affirmed by the superior court, the Commonwealth argued that both courts erred both in applying the probable cause standard set forth in Swanger and Murray and in ignoring the language of the statute. ${ }^{71}$ The supreme court rejected the notion. It concluded that "when we balance the underlying interests of the individual and the government, the two standards amount to nothing more than a distinction without a difference." "72 Again, it is important to note here that the court's decision did not come as a principle of statutory construction. Its conclusion that the language in the statute could mean nothing less than probable cause came after balancing the interests involved. This is the classic constitutional analysis that the court applied in Swanger and affirmed in Murray.

65. See id. at 417-18.

66. Swanger and Murray were both decided before the original version of title 75, section 6308(b) of the Pennsylvania Code was enacted. The significance of this point is minimal. The standards set forth in both cases, particularly in Swanger where a statutory provision was at issue, did not rest on the interpretation of any authority granted by the legislature. Although such authority may be given by statute, it may not go beyond the protections that the state constitution affords to citizens of the commonwealth.

67. 668 A.2d 1113 (Pa. 1995).

68. Id. at 1117 (citing 75 PA. Cons. STAt. § 6308(b) (2004)).

69. Id. at 1114 .

70. Id. at $1114-15$.

71. Id. at $1115-16$.

72. Id. at 1116 . I believe the court was being rather considerate here. It is certainly plausible that the legislature intended to statutorily lower the standard applicable to these kinds of stops in their first enactment of this provision. The court here seems to be reading the probable cause standard into the statutory language in order to avoid striking it down on constitutional grounds - something all high courts avoid if at all possible. The amended version of the statute, in its starkly different language, will hopefully not be met with the same benevolence. 
The court also rejected the Commonwealth's argument that the probable cause requirement in Swanger and Murray came only in response to the unlimited authority granted to police officers by the statute at issue in Swanger, title 75, section 1221(b) of the Pennsylvania Code. ${ }^{73}$ Essentially, the court repeated once again that probable cause, is probable cause, is probable cause. ${ }^{74}$ The standard is the same, no matter the statutory language that is used by the legislature to grant the authority to police officers. The court went on to note that when a police officer stops a vehicle for a violation of the Vehicle Code, no further investigation is necessary after the stop. Either the violation is witnessed, creating probable cause for the stop, or it is not; hence the distinction again between traffic stops and situations where it is necessary to stop a vehicle for suspected criminal activity (where further investigation is the precise purpose of the stop) ${ }^{75}$ Terry is therefore inapplicable, both on its law and its facts.

The final significant clarification of the law by the Supreme Court of Pennsylvania in this area came in Commonwealth $v$. Gleason. ${ }^{76}$ In that case, the defendant was cited for a non-DUI traffic offense. ${ }^{77}$ In customary fashion, upon approaching the defendant to issue the citation, the police officer "observed signs of intoxication and performed field sobriety tests," which lead to an ultimate arrest for driving under the influence of alcohol. ${ }^{78}$ On appeal from the defendant's denied motion to suppress, the superior court weighed the sufficiency of the evidence on a reasonable suspicion standard. ${ }^{79}$ The defendant argued that the superior court, in an unpublished decision, impermissibly lowered the standard as set forth in Whitmyer. ${ }^{80}$ The supreme court agreed. In assessing its holdings in Swanger, Murray, and Whitmyer, the court concluded, once again, that the presence of the statutory grant of authority did not change the probable cause requirement for traffic stops. In finding the stop of the defendant justified, the superior court had

73. Id. The statute was repealed in 1976 .

74. See id.

75. Id. at 1118 ("[T]his is not a case where further investigation would lead to a discovery of a violation of the Vehicle Code. If the trooper was unable to clock Appellee for three-tenths of a mile or observe the conditions that would warrant a citation for driving at an unsafe speed, there is no further evidence that could be obtained from a subsequent stop and investigation.").

76. 785 A.2d 983 (Pa. 2001).

77. Id. at 985 .

78. Id.

79. Id. at 986 .

80. Id. 
impermissibly lowered the standard necessary for a proper vehicle stop to reasonable suspicion. ${ }^{81}$

A series of superior court opinions handed down between Whitmyer and Gleason further confused the law. In Commonwealth v. Baumgardner, ${ }^{82}$ Commonwealth v. Howard, ${ }^{83}$ Commonwealth v. Masters, ${ }^{84}$ and Commonwealth v. Lawrentz, ${ }^{85}$ the superior court deviated from the supreme court's pronouncement in Whitmyer and applied a reasonable suspicion standard in each case. As one commentator has noted:

[I]n light of the Pennsylvania Supreme Court's longstanding commitment to probable cause as the standard, judicial opinions stating or implying that reasonable suspicion is the standard simply should not be issued. While reasonable jurists and attorneys may differ over how poorly a motorist must drive to reach the threshold of probable cause, it is sad to find that Pennsylvania's lower courts have often failed to apply the correct standard. ${ }^{86}$

The superior court's somewhat confusing decisions in this area not only apply the wrong standard, but since many of them were never appealed to the state supreme court, they also left unchallenged law on the books until the Pennsylvania Supreme Court's decision in Gleason. Having two apparent standards in the commonwealth during this period no doubt confused judge and practitioner alike. ${ }^{87}$ Indeed, another commentator has noted:

81. Id. at 989. The court cited a very large portion of the Whitmyer opinion in its analysis. In doing so, it reiterated the point that the basis of the court's previous decisions regarding the probable cause standard were not based on statutory interpretation. As discussed above, the court rejected this argument in Whitmyer and Gleason. The analysis was based on the competing interests of citizen privacy and public road safety. In each case, inevitably because of the right to privacy under article I, section 8 of the Pennsylvania Constitution, the citizens' right to be left alone tipped the scale. See generally Commonwealth v. Whitmyer, 668 A.2d 1113, 1115-18 (Pa. 1995); Commonwealth v. Gleason, 785 A.2d 983, 988-89 (Pa. 2001).

82. 767 A.2d 1065 (Pa. Super. Ct. 2001), rev'd, 796 A.2d 965 (Pa. 2002).

83. 762 A.2d 360 (Pa. Super. Ct. 2000).

84. 737 A.2d 1229 (Pa. Super. Ct. 1999).

85. 683 A.2d 303 (Pa. Super. Ct. 1996).

86. Jacob C. McCrea, Comment, Reasonable Suspicion, Probable Cause, or Something in Between: What is the Standard for a Valid Vehicle Stop in Drunk Driving Cases, And Will Courts Adhere to the Standard?, 42 DuQ. L. Rev. 559, 573-74 (2004). McCrea puts forth an excellent summary of the law in this area up to and through the Gleason opinion. He argues that not only has probable cause been the unwavering standard of the state supreme court, but also that Terry does not provide an appropriate standard to govern traffic stops. Id. at 575.

87. McCrea also notes how " $[\mathrm{r}]$ ambling dicta and the careless use of terms of art in judicial opinions describing the standard add to the confusion surrounding this issue." Id. at 574. 
[S]ince Gleason, it also appears clear that the [Pennsylvania] Supreme Court will no longer tolerate the lesser standard of articulable and reasonable grounds for traffic stops. Rather, if the alleged basis of the traffic stop is to permit a determination of whether there was compliance with the Vehicle Code, it is incumbent upon the police officer to articulate specific facts possessed by him, at the time of the questioned stop, which would provide probable cause to believe the vehicle or the driver was in violation of a particular section of the Vehicle Code. ${ }^{88}$

The problems with the conclusion here are clear. First, the Pennsylvania Supreme Court never tolerated a lesser standard for traffic stops - the standard has always been probable cause. The main reason that the reasonable suspicion standard has weighed in the analysis of opinions in the commonwealth is the superior court's current entertainment of this standard in traffic stop cases. Second, a cursory review of the law brings about the conclusion that the "articulable and reasonable grounds" statutory standard meant nothing less than probable cause. In Whitmyer, the supreme court wrote this interpretation into its own jurisprudence.

In 2004, in response to the court's holding in Gleason, the Pennsylvania legislature lowered the statutory level of suspicion required for police officers to make traffic stops. ${ }^{89}$ Any hope of clarity in the law after Gleason was now extinguished. In a series of difficult cases, the superior court effectively deviated from the supreme court's standard. Although the probable cause rule was not ever based on statutory interpretation, the legislature's decision to lower the standard apparently held preeminent sway with the superior court.

Before I turn my attention to those cases, however, one trial court opinion is worth noting. In Commonwealth v. Erdley, ${ }^{90}$ the Court of Common Pleas of Armstrong County ruled on a suppression motion brought by a defendant stopped for allegedly violating the Motor Vehicle Code. ${ }^{91}$ The defendant argued that the police officer did not have probable cause to make the stop, and the court agreed and granted the motion. ${ }^{92}$ The trial court took into consideration that the statutory standard governing this area had recently been changed by the legislature to require only reasonable suspicion. However, because of the supreme court's ruling in Gleason, the trial court applied the

88. Joseph E. Vogrin, III, DUI Traffic Stops in Pennsylvania: Changed Forever After Gleason and its Progeny, 5 Lawyers. J., Feb. 7, 2003, at 6, available at 5 No. 3 Lawyers J. 6 (WestLaw).

89. 75 Pa. Cons. Stat. AnN. $§ 6308$ (b) (West 2004). As amended, the statute now uses the express term "reasonable suspicion." Id.

90. 75 Pa. D. \& C.4th 564 (Pa. C.P. Ct. Armstrong County 2005).

91. Id. at 566; see also 75 PA. Cons. STAt. AnN. § 3702 (West 1996) (limitations on backing).

92. Id. at 568 . 
probable cause standard, notwithstanding any statutory language to the contrary. ${ }^{93}$

The superior court's first significant run-in with the amended statute and its validity came in Commonwealth v. Sands. ${ }^{94}$ In Sands, the defendant was stopped by a police officer after the officer had followed him for several miles. ${ }^{95}$ Upon stopping the defendant, the officer detected a strong odor of alcohol. After approaching the defendant and speaking with him, the officer noticed that the defendant also used slurred speech and had bloodshot eyes. ${ }^{96}$ The defendant was charged and convicted of both driving under the influence and not driving in a single lane. ${ }^{97}$ However, it is unclear from the record as reviewed by the superior court which offense lead to the initial stop. The court apparently saw no significance in the distinction. The defendant brought an appeal before the superior court, challenging the constitutionality of the amended version of section 6308(b). In addressing the challenge, the superior court assumed that the justification for the stop was a perceived violation of the DUI provision of the Motor Vehicle Code. In its analysis, the court addressed the standard set out in Swanger, Murray, Whitmyer, and Gleason, and concluded that "all these cases reaffirm the court's holding in Whitmyer that the police must have probable cause to stop a vehicle for a suspected violation of the Vehicle Code." 98

The court argued, however, that unlike the scenario in Whitmyer, in a situation where the initial stop was based on a perceived DUI violation, a further investigation would serve valid purposes. ${ }^{99}$ In doing so, the court recognized that courts in Pennsylvania treat vehicular stops differently depending on the nature of the suspected violation of the Vehicle Code. ${ }^{100}$ As

93. Id. at 567-68. The court specifically stated: "The new version of $\S 6308(\mathrm{~b})$, which became effective February 1, 2004, appears to create a less stringent standard for making a lawful traffic stop. However, in view of the Pennsylvania Supreme Court's ruling in Commonwealth v. Gleason, that the probable cause standard applies to traffic stops under the Fourth Amendment to the U.S. Constitution, regardless of whatever other statutory language authorizes such stops, it appears that probable cause continues to be the applicable standard and the court will apply that standard here." Id. (citation omitted).

94. 887 A.2d 261 (Pa. Super. Ct. 2005).

95. Id. at 264 .

96. Id.

97. Id. at 262; see 75 PA. Cons. StAT. Ann. §§ 3802(a)(1), (c), 3309(1) (West 2006).

98. Sands, 887 A.2d at 267 .

99. Id. at 270. The court noted that "a suspected violation for DUI is in fact a scenario where further investigation almost invariably leads to the most incriminating type of evidence, i.e., strong odor of alcohol, slurred speech, and blood shot eyes. This type of evidence can only be obtained by a stop and investigation." Id.

100. Id. at 270 . 
a result, the court held that "the limited intrusion permitted by Section 6308(b) in the case of a vehicular stop based upon a reasonable suspicion that the driver is driving under the influence, as balanced against the Commonwealth's salutary interest in preventing DUI violations, violates neither the Fourth Amendment nor Article I, Section 8." 101 Only the constitutionality of the statute regarding DUI stops was addressed. This conclusion, of course, does not get past the fact that the statute applies to all stops under the Motor Vehicle Code, including those of a non-DUI nature. It also does not sufficiently deal with the point that, although the court in Whitmyer stated that further investigation would not have any value in the cases of a non-DUI violation, the standard announced in Whitmyer applies to all traffic stops, however construed. ${ }^{102}$

The superior court in Sands addressed, to an extent, the legislative intent behind the statute. It concluded that the intent behind the statute was addressed specifically at DUI cases, and in that capacity, the legislative intent was valid. ${ }^{103}$ While the court's conclusion about legislative intent is correct, the problems that it presents are clear. The legislature intended to lower the standard regarding DUI stops. However, as the DUI statute remains part of the Motor Vehicle Code, attempts to lower the constitutional standard set by the Supreme Court of Pennsylvania will affect all provisions in the Code, however minor. It is true that the Pennsylvania Supreme Court has permitted the reasonable suspicion standard to govern Terry-type automobile stops when criminal activity may be afoot (e.g., the court's example of vehicular homicide). Obviously, that crime is not part of the Motor Vehicle Code. And so, the legislature, intending to "lower" the standard regarding DUI stops because of their proximity to other criminal activity, in effect lowered the standard for DUI stops and other minor violations under the Motor Vehicle

101. Id. at 271-72. The court noted: "[O]ur decision here is limited to the constitutionality of Section 6308(b) in so far as it permits an officer to stop a vehicle based upon a reasonable suspicion that the driver is operating the vehicle under the influence of alcohol. Thus, we are not here addressing whether the statute comports with federal and state constitutional protections discussed in cases such as Gleason or Whitmyer where the suspected violation was not DUI." Id. at 270.

102. Even though the reasonableness of DUI stops based on reasonable suspicion may not be as questionable as normal traffic stops, the apparent inconsistency between the standards will remain as long as the criminal DUI statutes remain part of the Motor Vehicle Code. In lumping different levels of suspicion into a single statute, the legislature has, in effect, created its own problem.

103. Sands, 887 A.2d at 268 . There are additional problems with the legislative history relied upon by the superior court in coming to their conclusion. I will address them in the policy section of my analysis. 
Code. ${ }^{104}$ The analysis for each type of violation, however, is not governed by such a uniform standard.

A second major case involving the newly amended statute is Commonwealth v. Ulman. ${ }^{105}$ In Ulman, the defendant was stopped by a police officer for two alleged violations of the Vehicle Code: driving at an unsafe speed and failing to proceed through an emergency response area with caution. ${ }^{106}$ The defendant was ultimately charged with DUI, but it is unclear from the opinion whether the original violations were ever prosecuted. ${ }^{107}$ At trial, the defendant's suppression motion was denied. On appeal, the superior court rested its entire opinion on the amended version of the statute. The court did not address the constitutionality of the statute as applied to non-DUI stops, but it did note that regarding DUI stops, the court in Sands found the statute to be constitutionally firm. ${ }^{108}$ The court proceeded to disregard all of the appellant's arguments because appellant alluded to cases prior to the 2004 amendment, which, according to the court, no longer applied. ${ }^{109}$ The court then concluded:

The legislative history of this amendment clearly indicates that it was the Legislature's intent to authorize police officers to stop a vehicle based upon a "reasonable suspicion" that the driver has violated the Vehicle Code, rather than the heightened standard of probable cause which was applied in Whitmyer. Since Whitmyer was decided under former Section 6308(b), which required a stricter standard for a traffic stop than the current version of the statute, Whitmyer is not controlling precedent in the present matter. ${ }^{110}$

The court's reasoning is not only erroneous, but it is also circular. First, as I have pointed out up to this point, the court's decision in Whitmyer (and Murray and Swanger) was not based on statutory interpretation. Furthermore,

104. This problem is the very reason why some states have separated their DUI statutes from their vehicle codes, making the latter non-criminal.

105. 902 A.2d 514 (Pa. Super. Ct. 2006), appeal denied, 916 A.2d 1102 (Pa. 2007).

106. Id. at 516 .

107. The facts in this case were not fully recounted. The court stated: "When officer Lash approached the vehicle, he saw that it was driven by Appellant. It is undisputed that at the time of the traffic stop Appellant's blood alcohol content was above the legal limit." Id. The case does not provide the method by which the BAC was tested, the citation of the traffic offenses, or any other procedural facts from the encounter.

108. Id. at 517. The purpose of this conclusion is unclear. The DUI-relatedness of the Sands analysis makes it of little relevance in Ulman. See also id. at 517 n.3 (noting Judge Gantman's dissent in Commonwealth v. Anderson and questioning the validity of the statutory amendment). Again, as in Anderson, the issue was not properly presented to the court in Ulman.

109. Ulman, 902 A.2d at 517.

110. Id. at 518 (citation omitted). 
the "stricter standard" that the court speaks of was read into the statute in Whitmyer by the Pennsylvania Supreme Court itself. Basically, the superior court in Ulman concluded that because the prior statute, as interpreted in Whitmyer, required a heightened standard, and the legislature clearly intended to lower the standard, Whitmyer no longer applies because it was decided under the prior version of the statute, which required a stricter standard as interpreted in Whitmyer, etc. ... The reasoning is tortured indeed. The Ulman court finally concluded that the police officer in Ulman had reasonable suspicion to stop the defendant, and the conviction for DUI was affirmed. ${ }^{111}$

One might ask: What is the difference between these two standards? Regarding traffic stops, the distinction may not seem to make a big difference. I will address the significance of the distinction in more depth in the policy section of this Note, but it is important to note now that the standards have taken on different meanings in Pennsylvania. For example, in Commonwealth v. Barber, ${ }^{112}$ the superior court stated that to meet the standard of reasonable suspicion, an officer must

\footnotetext{
point to specific and articulable facts which, together with the rational inferences therefrom, reasonably warrant the intrusion. "In ascertaining the existence of reasonable suspicion, we must look to the totality of the circumstances to determine whether the officer had reasonable suspicion that criminal activity was afoot."

". . . [P]olice officers need not personally observe the illegal or suspicious conduct, but may rely upon the information of third parties, including 'tips' from citizens." 113
}

111. Id. at 519. The Pennsylvania Superior Court has been presented with the issue of the constitutionality of section 6308(b), in one form or another, on several occasions. It declined each time to squarely address the issue. See, e.g., Commonwealth v. Spease, 911 A.2d 952, 959 (Pa. Super. Ct. 2006). The defendant in Spease challenged the constitutionality of section 6308(b), this time specifically under article I, section 8. The court, with no analysis, concluded that "Sands is binding upon this Court and we are not at liberty to overrule it." Id. See also Commonwealth v. Little, 903 A.2d 1269, 1272 (Pa. Super. Ct. 2006) (declining to consider the constitutionality of section 6308(b) because the defendant did not properly perserve the issue for appeal); Commonwealth v. Cook, 865 A.2d 869, 873 n.1 (Pa. Super. Ct. 2004) (disregarding any constitutionality concerns as being beyond the scope of their decision since the stop satisfied the higher probable cause standard).

112. 889 A.2d 587 (Pa. Super. Ct. 2005).

113. Barber, 889 A.2d at 593 (emphasis added) (quoting Commonwealth v. Wiley, 858 A.2d 1191, 1194 (Pa. Super. Ct. 2004) and Commonwealth v. Lohr, 715 A.2d 459, 461 (Pa. Super. Ct. 1998)). Not only does the officer not necessarily have to observe the suspected activity, he does not need actual knowledge that the activity not being witnessed is criminal. See Commonwealth v. Rogers, 849 A.2d 1185, 1189 (Pa. 2004). 
It is clear that to meet the reasonable suspicion standard, a police officer need not actually observe the traffic violation in order to stop the driver. ${ }^{114}$ The probable cause standard is different; to have probable cause, a police officer will almost necessarily have to observe the traffic violation before he may pull the defendant over. Indeed, a violation alone may not be enough in some circumstances. In Commonwealthv. Garcia,${ }^{115}$ the police officer observed the defendant drive over the right berm line two times, each time maneuvering in response to other oncoming vehicles. ${ }^{116}$ The conduct took place over a twoblock area. ${ }^{117}$ The superior court concluded that "where a vehicle is driven outside the lane of traffic for just a momentary period of time and in a minor manner, a traffic stop is unwarranted." 118 Similarly, in Commonwealth v. Battaglia ${ }^{119}$ the court concluded that an officer's perception that a defendant was driving erratically because he weaved within his lane, drove five to ten miles per hour under the speed limit, and crossed over the white fog line, was insufficient to establish probable cause to support the ensuing traffic stop. ${ }^{120}$ The practical difference between the two standards is clear, even if the legal distinction is hazy. ${ }^{121}$

\section{Other Independent Analyses}

A long line of cases in which the Supreme Court of Pennsylvania addressed federal constitutional cases and their application in Pennsylvania

114. The United States Supreme Court has also noted that "[r]easonable suspicion is a less demanding standard than probable cause not only in the sense that reasonable suspicion can be established with information that is different in quantity or content than that required for probable cause, but also in the sense that reasonable suspicion can arise from information that is less reliable than that required to show probable cause." Alabama v. White, 496 U.S. 325, 330 (1990).

115. 859 A.2d 820 (Pa. Super. Ct. 2004).

116. Id. at 821 .

117. Id. at 823 .

118. $I d$.

119. 802 A.2d 652 (Pa. Super. Ct. 2002).

120. Id. at 657 . The court concluded, particularly regarding DUI violations, that "we might extract the conclusion that there is no basis for 'profiling' a suspected drunk driver merely on the basis of observing undisciplined operation of a vehicle which does not form the basis for a conclusion that there has been a violation of the Vehicle Code." Id.

121. One of the main causes of this haziness, particularly in Pennsylvania cases, is the confused state of the arguments at the trial level. Because the standard has been unstable and unsure for many years, attorneys have, quite erroneously, argued in suppression motions that a particular search or seizure did not have probable cause or reasonable suspicion to support it. The courts make their conclusions of law accordingly, either affirming that the search or seizure had both probable cause and reasonable suspicion, or concluding that it had neither. 
also supports a conclusion that the reasonable suspicion standard, as applied to traffic stops, is not acceptable under the Pennsylvania Constitution. In fact, in each case where the Pennsylvania Supreme Court undertook an independent analysis under the Pennsylvania Constitution, it relied on the semantic differences between article I, section 8 and the Fourth Amendment in refusing to apply federal precedent to Pennsylvania case law. First, in Commonwealth v. DeJohn, ${ }^{122}$ the state supreme court refused to adopt the United States Supreme Court's decision in United States v. Miller. ${ }^{123}$ The Court in Miller held that the Fourth Amendment did not protect a depositor from the seizure of his bank records. ${ }^{124}$ In recognizing that article I, section 8 specifically embodies a privacy right not found in the Fourth Amendment, the court in DeJohn held that in Pennsylvania, under the state constitution, bank customers have a legitimate expectation of privacy in records pertaining to their affairs at the bank. ${ }^{125}$

Later, in Commonwealth v. Sell, ${ }^{126}$ the Pennsylvania Supreme Court was once again faced with an issue that would force it to decide whether or not to adopt a United States Supreme Court holding. In Sell, the issue was "whether, under Article I, section 8 of the Pennsylvania Constitution, which guarantees the citizens of this Commonwealth protection against unreasonable searches and seizures, a defendant accused of a possessory crime will continue to have 'automatic standing' to challenge the admissibility of evidence alleged to be the fruit of an illegal search and seizure." 127 The United States Supreme Court, in United States $v$. Salvucci, ${ }^{128}$ abolished the automatic standing rule in favor of the "legitimate expectation of privacy" test. ${ }^{129}$ In order to bring a motion to suppress allegedly illegal evidence, one would have to show a reasonable expectation of privacy in the thing seized. ${ }^{130}$ The court in Sell declined to adopt that approach in Pennsylvania, again stressing the differences between the two provisions and the heightened protections of

122. 403 A.2d 1283 (Pa. 1979).

123. 425 U.S. 435 (1976).

124. The Supreme Court's rationale was that a depositor had no reasonable expectation of privacy in bank records (which the court saw as property of the bank). Hence, the protections of the Fourth Amendment were not implicated.

125. DeJohn, 403 A.2d at 1291 . The court noted that because "Miller establishes a dangerous precedent, with great potential for abuse, we decline to follow that case when construing the state constitutional protection against unreasonable searches and seizures.” Id. at 1289.

126. 470 A.2d 457 (Pa. 1983).

127. Id. at 458 .

128. 448 U.S. 83 (1980).

129. Id. at 94 .

130. Id. 
article I, section $8 .{ }^{131}$ Automatic standing to bring a motion to suppress would remain part of Pennsylvania's search and seizure jurisprudence.

A third significant case in this line of decisions is Commonwealth $v$. Johnston. ${ }^{132}$ In Johnston, the issue before the court was whether the "warrantless use of drug detection dogs in the corridors of leased storage areas is permitted under Pennsylvania law." 133 In a broader sense, the issue was whether or not the United States Supreme Court's decision in United States v. Place ${ }^{134}$ would apply in Pennsylvania. In Place, the Court used a balancing test to determine whether or not the particular drug dog tactics (the "canine sniff") used in the case constituted a search. ${ }^{135}$ In Johnston, another drug dog case with slightly dissimilar facts, the Pennsylvania Supreme Court refused to adopt the balancing approach to determine whether or not the incident at issue was, in fact, a search. ${ }^{136}$ Such tests, it concluded, were only appropriate in Terry situations where the exigencies involved would require quick reactions by the police officer. ${ }^{137}$ The court consequently held that the "canine sniff" falls into a Fourth Amendment "middle ground" and that the police could only use drug detection dogs to test for the presence of narcotics in limited circumstances. ${ }^{138}$ While the court's deviance from the federal standard was not explicitly predicated on article I, section 8 , it necessarily must have been so. The court not only cited article I, section 8 in its analysis, but its deviance from that standard indicated a consideration of factors beyond federal law. If the holding in Johnston rested solely on the Federal Constitution, the court would technically not be free to deviate from the United States Supreme Court's holding in Place.

The most recent case in which Supreme Court of Pennsylvania deviated from federal precedent is Commonwealth v. Matos. ${ }^{139}$ In Matos, the court, using an Edmunds analysis, ${ }^{140}$ analyzed whether the United States Supreme

131. Sell, 479 A.2d at $467-69$.

132. 530 A.2d 74 (Pa. 1987).

133. Id. at 78 .

134. 462 U.S. 696 (1983).

135. Id. at 703 .

136. Johnston, 530 A.2d 79.

137. Id. According to the Johnston court, the exigencies required for Terry to apply were not present in the case. $I d$.

138. Id. The court held that the detection tactics could only be used when "(1) the police are able to articulate reasonable grounds for believing that drugs may be present in the place they seek to test; and (2) the police are lawfully present in the place where the canine sniff is conducted." Id.

139. 672 A.2d 769 (Pa. 1996).

140. It should not be forgotten that in Edmunds itself the court declined to follow federal precedent in construing article I, section 8 (regarding the good faith exception to the exclusionary rule). Edmunds is 
Court's decision in California v. Hodari D. ${ }^{141}$ would apply in Pennsylvania. In Hodari D., the defendant, upon pursuit by police officers, fled a crime scene and was subsequently tackled and arrested. ${ }^{142}$ Before he was apprehended, the defendant discarded a rock of crack cocaine which was later recovered and confiscated by police. ${ }^{143}$ The Court held that the evidence was not excludable because no arrest had been performed at the time the drugs were discarded. ${ }^{144}$ The pursuit by police did not involve any physical force with lawful authority or any submission to the assertion of such authority. ${ }^{145}$ Therefore, no seizure occurred. In Matos, the Pennsylvania Supreme Court declined to adopt the federal definition of "seizure." 146 In doing so, the court emphasized:

This Court has clearly and emphatically recognized that our citizens enjoy a strong right of privacy, and that our citizens are therefore entitled to broader protection in certain circumstances under our state constitution.

$\cdots$

Accordingly, we reject Hodari $D$. as incompatible with the privacy rights guaranteed to the citizens of this Commonwealth under Article I, section 8 of the Pennsylvania Constitution. ${ }^{147}$

The court also emphasized the policy reasons in declining to adopt the holding of Hodari D. Citing Commonwealth v. Rodriguez, ${ }^{148}$ the court noted that it had rejected in that case the contention that the goal of curtailing the drug trade permits expansion of police intrusion without the constitutional justification of reasonable suspicion or probable cause:

We emphatically reject the Superior Court's "end justifies the means" analysis. By focusing its attention only upon the serious ills inflicted upon society by illegal

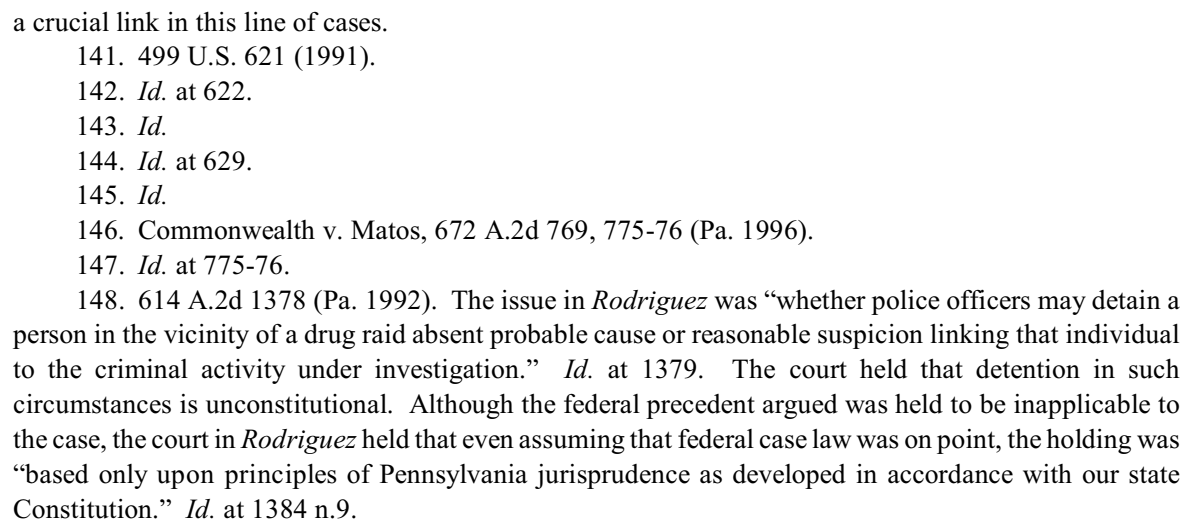
person in the vicinity of a drug raid absent probable cause or reasonable suspicion linking that individual to the criminal activity under investigation." Id. at 1379. The court held that detention in such circumstances is unconstitutional. Although the federal precedent argued was held to be inapplicable to the case, the court in Rodriguez held that even assuming that federal case law was on point, the holding was "based only upon principles of Pennsylvania jurisprudence as developed in accordance with our state Constitution." Id. at 1384 n.9. 
narcotics, the Superior Court failed to recognize and respond to necessary constitutional constraints on excessive police conduct. The seriousness of criminal activity under investigation, whether it is the sale of drugs or the commission of a violent crime, can never be used as justification for ignoring or abandoning the constitutional right of every individual in this Commonwealth to be free from intrusions upon his or her personal liberty absent probable cause. ${ }^{149}$

\section{Case Law Conclusions}

These two lines of cases interpreting article I, section 8 of the Pennsylvania Constitution and its applicability to illegal searches and seizures reveal some clear principles. First, probable cause is the standard that has always been applied to routine traffic stops in Pennsylvania. The only reason for the confusion as of late is the misunderstanding of the Pennsylvania Supreme Court's distinction between traffic stops and traditional Terry situations where the reasonable suspicion standard still appropriately applies. Any inconsistency found in the Vehicle Code between non-DUI and DUI stops results not from the problem with the law, but from the problem of having DUI statutes included in the Motor Vehicle Code itself. DUI stops may in fact be justified on a reasonable suspicion standard. In this situation, the facts of Terry are not as distant as they are in situations involving normal traffic stops, where none of the elements of Terry are present: (1) there is no reason to investigate further upon making the stop; (2) there is little, if any, exigency; (3) there is no initial fear that the drivers of the vehicle are armed and dangerous; and (4) the "criminal activity" that is afoot has already been observed by the patrolling police officer, instantly giving him or her probable cause to make the stop to issue the citation. Not only has the distinction between the two situations been effectively lost on the Pennsylvania Superior Court, but the analysis starting all the way back with Murray and Swanger is inconsistent. Furthermore, any conclusions that the Pennsylvania Supreme Court "raised" the standard in cases like Whitmyer and Gleason are simply wrong. Those two cases merely reasserted what the supreme court has been saying for the last thirty years: notwithstanding legislative intent to the contrary, to make a valid traffic stop in the Commonwealth of Pennsylvania, a police officer must have probable cause that either the driver or his vehicle is in violation of the Motor Vehicle Code. And, most importantly, the principle is one of constitutional law, not legislative enactment. 
The second line of cases discussed above reiterates the fact that the Pennsylvania Supreme Court, more than most states in the Union, has deviated from United States Supreme Court standards in cases where the express right to privacy found in article I, section 8 is threatened by federal precedent. Moreover, the pre- and post-Edmunds cases in this vein of jurisprudence reveal that when the privacy interest embodied in the state constitution is threatened, only serious societal interests may justify even limited intrusions upon that right. And, since the purposes of the Fourth Amendment and article I, section 8 are markedly different, the policies justifying any deviance from strict probable cause requirements will differ depending on which constitutional provision is involved.

\section{Other States’ Treatment of Traffic Stops}

No state, to my knowledge, has yet specifically addressed how its own constitution independently treats the standard to make routine traffic stops. Some inferences can be made from a few of the state cases, but before I turn to them, I want to address the apposite federal standard. In DeJohn, ${ }^{150}$ the Pennsylvania Supreme Court noted:

\footnotetext{
State judges, however, need not ignore the reasoning of the United States Supreme Court in opinions rejecting a comparable federal constitutional claim. For a state court interpreting a state constitution, opinions of the United States Supreme Court are like opinions of sister state courts or lower federal courts. While neither binding in a constitutional sense nor precedential in a jurisprudential one, they are entitled to whatever weight their reasoning and intellectual persuasiveness warrant. ${ }^{151}$
}

In assessing the limited federal case law on point in traffic stop situations, I note here that, although it is clear that the Pennsylvania Constitution permits, and possibly requires, that the state exceed a lower federal standard, the federal standard itself may not even be a less protective one. The United States Supreme Court has never directly addressed the requisite standard to be applied to routine traffic stops. In the cases that come close, it is anything but clear that reasonable suspicion is an acceptable standard.

In Delaware v. Prouse, ${ }^{152}$ the Supreme Court presented the issue as

150. Commonwealth v. DeJohn, 403 A.2d 1283 (Pa. 1979).

151. Id. at 1289 (citing Jerome B. Falk, Jr., The State Constitution: A More Than "Adequate" Nonfederal Ground, 61 CAL. L. REV. 273, 283-84 (1973)).

152. 440 U.S. 648 (1979). 
whether it is an unreasonable seizure under the Fourth and Fourteenth Amendments to stop an automobile, being driven on a public highway, for the purpose of checking the driving license of the operator and the registration of the car, where there is neither probable cause to believe nor reasonable suspicion that the car is being driven contrary to the laws governing the operation of motor vehicles or that either the car or any of its occupants is subject to seizure or detention in connection with the violation of any other applicable law. ${ }^{153}$

While it is unclear at first blush precisely what the two stated standards in this passage refer to, the language contemplates an application of both probable cause and reasonable suspicion. In Prouse, a police officer stopped the defendant in his automobile and, upon conversing with him, smelled marijuana smoke and noticed a bag containing the drug in plain view on defendant's car floor. ${ }^{154}$ At the suppression hearing, the police officer testified that he had "observed neither traffic or equipment violations nor any suspicious activity, and that he made the stop only in order to check the driver's license and registration." 155 The Court held that the evidence obtained from the seizure should have been excluded and affirmed the decision of the Delaware Supreme Court that the stop was unconstitutional. ${ }^{156}$ In doing so, the Court decided the case, as is common, on the narrowest possible grounds. Where at least reasonable suspicion is not present, the stopping of an automobile driver is unconstitutional. ${ }^{157}$

The Supreme Court's reckless use of language in Prouse is disheartening. While the Court's holding seems to set reasonable suspicion as the pertinent floor under which police officers cannot go, in the stated issue at the beginning of the opinion and throughout the Court's discussion, the language is confused. Later on, Justice White concludes:

153. $I d$. at 650 . It is not clear whether the two standards enunciated here address separately the two situations contemplated by the court. A possible understanding of the issue presented is that "probable cause to believe" relates to when "the car is being driven contrary to the laws governing the operation of motor vehicles" and "reasonable suspicion" governs situations where "either the car or any of its occupants is subject to seizure or detention in connection with the violation of other applicable law." Id. If the standards and the situations to which they apply are bifurcated in the sentence structure, this is certainly a plausible reading. If not, it is indeed a careless confusion of the two terms of art.

154. Id.

155. Id.

156. Id. at 663 .

157. Id. The court specifically held that "except in those situations in which there is at least articulable and reasonable suspicion that a motorist is unlicensed or that an automobile is not registered, or that either the vehicle or an occupant is otherwise subject to seizure for violation of law, stopping an automobile and detaining the driver in order to check his driver's license and the registration of the automobile are unreasonable under the Fourth Amendment." Id. at 663. Admittedly, this holding does not squarely answer the issue that the court presented at the outset of the opinion. 
When there is not probable cause to believe that a driver is violating any one of the multitude of applicable traffic and equipment regulations - or other articulable basis amounting to reasonable suspicion that the driver is unlicensed or his vehicle unregistered - we cannot conceive of any legitimate basis upon which a patrolman could decide that stopping a particular driver for a spot check would be more productive than stopping any other driver. ${ }^{158}$

This language seems to fit the Court's issue a bit better than its formal holding, especially since the it mentions the probable cause standard and its applicability. However, it remains unclear from the Court's analysis which scenarios require probable cause and which scenarios require reasonable suspicion. Probable cause apparently fits somewhere in the mix, but the Court refrained from telling us just where.

Quite a few years later, in Whren v. United States, ${ }^{159}$ the Court again was presented with a traffic stop situation. ${ }^{160}$ Rather than addressing the level of suspicion required, the Court instead addressed the validity of admittedly pretextual stops. ${ }^{161}$ At the outset, the Court pointed out that the parties had stipulated to the fact that the officer did have probable cause to stop the defendant. ${ }^{162}$ Also at the outset of the opinion, the Court, citing Prouse and Pennsylvania v. Mimms, ${ }^{163}$ noted that "[a]s a general matter, the decision to stop an automobile is reasonable where the police have probable cause to believe that a traffic violation has occurred." ${ }^{164}$ While the specific issue of pretext addressed in Whren does not squarely concern my analysis here, the Court's analysis in upholding the seizure is relevant. In concluding that Prouse, regarding pretext, was not controlling in the case at hand, the Court stated:

Our opinion in Prouse expressly distinguished the case from a stop based on precisely what is at issue here: "probable cause to believe that a driver is violating any one of the multitude of applicable traffic and equipment regulations." It noted approvingly that "[t]he foremost method of enforcing traffic and vehicle safety regulations ... is acting upon observed violations," which afford the "quantum of

158. Id. at 661 .

159. 517 U.S. 806 (1996).

160. Id. at $808-09$.

161. Id. at 813 .

162. Id. at 810 .

163. 434 U.S. 106 (1977).

164. Whren, 517 U.S. at 810 . No doubt the court here contemplated that in situations where the police officer has reasonable suspicion that other criminal activity is afoot, or that the occupants of the vehicle had participated in a crime, the stop could be reasonable under a Terry analysis. 
individualized suspicion" "necessary to ensure that police discretion is sufficiently constrained. ${ }^{165}$

The Court's interpretation of Prouse here sheds some light on the contemporary understanding of Whren's holding. As quoted above, the Court noted the Prouse Court's suggestion that the best way to protect against abuses of police discretion is to require the police to act upon "observed violations" that provide the "quantum of individualized suspicion" necessary for the seizure to be reasonable. That level of suspicion, albeit permissibly pretextual since Whren, is likely probable cause.

\section{Policy}

The fourth prong of the Edmunds analysis requires a consideration of the competing policy arguments underlying the issue involved. There is no better place to start than the statement of legislative intent underlying the amended version of section 6308(b). During deliberations of the bill that became the current version of section 6308(b), one representative noted:

Pennsylvania courts have recently discarded the reasonable suspicion justification for making traffic stops in DUI cases. ... .

... Gleason has created an untenable double standard for justifying traffic stops in Pennsylvania. Pennsylvania courts now require probable cause to make a traffic stop based on a Vehicle Code offense while reasonable suspicion is sufficient for other traffic stops. ...

$\ldots$

... [F]inally, Mr. Speaker, in the bill currently under consideration, we have used the phrase "reasonable suspicion" which satisfies the requirements of the United States Constitution and the Pennsylvania Constitution and accurately balances the dangers of drunken driving with the right of any citizen to be secure in his person. ${ }^{166}$

The Pennsylvania Superior Court in Sands ${ }^{167}$ in finding that the statute as applied in DUI cases did not violate either the Fourth Amendment or article I, section 8 , concluded:

Clearly, the legislature's intent was to permit officers who suspect that an operator of a vehicle has committed a serious offense, such as DUI or homicide by vehicle, to stop the vehicle based upon a reasonable suspicion rather than the heightened standard of probable cause . . . since existing constitutional precedent actually

165. Id. at 817-18 (quoting Delaware v. Prouse, 440 U.S. 648, 661, 659, 654-55 (1979)).

166. Legislative Journal of Pennsylvania - House, 185th of the General Assembly, at 1445-46 (July 8, 2003) (comments of Rep. Harper).

167. Commonwealth v. Sands, 887 A.2d 261 (Pa. Super. Ct. 2005). 
permits police officers to stop a vehicle based upon reasonable suspicion that criminal activity is afoot. ${ }^{168}$

The problems with both the legislature's interpretation of the law and with the superior court's assessment are glaring. First, the legislature's argument that the Pennsylvania Supreme Court in Gleason "discarded" the reasonable suspicion standard for DUI stops is plainly false. The standard for traffic stops under the Motor Vehicle Code has always been probable cause, and any application of the reasonable suspicion standard in DUI situations only makes sense because the Terry reasonable suspicion standard is relevant in that scenario. I must reiterate here that the apparent inconsistency between the treatment of DUI and other traffic stops results not from an illogical or "untenable" double standard imposed by the Supreme Court of Pennsylvania, but from the legislature's failure to realize the inherent difference between the two. As long as DUI violations remain part of the Motor Vehicle Code, and stops for potential DUI violations are governed by the same Code, the standard will remain, on its face, the same.

Secondly, the legislature misunderstands why the supreme court requires "probable cause to make a traffic stop based on a Vehicle Code offense while reasonable suspicion is sufficient for other traffic stops." 169 This distinction goes all the way back to Murray and Swanger, and it was reaffirmed in Whitmyer and Gleason. Unfortunately, the superior court and many practitioners have opted to discard it in their day-to-day suppression motion analyses. The distinction mirrors that in Terry. Certain vehicle stops, when it is suspected that real criminal activity is afoot, are justifiable under the reasonable suspicion standard. The court in Sands referenced this kind of a situation when it alluded to "DUI or homicide by vehicle" crimes. ${ }^{170}$ The superior court, although via a slightly misunderstood interpretation of the legislature's intent, correctly coupled DUI with vehicle by homicide rather than with, say, driving at an unsafe speed. DUI violations are better analogized to non-Motor Vehicle Code "crimes," particularly with regard to the level of suspicion required to make an automobile stop because of a perceived violation. If the legislature comes to recognize this misalignment, the "untenable" standard imposed by the state supreme court will no doubt come into abrupt focus.

168. Id. at 268

169. $I d$.

170. See id. at 268. 
A second policy problem underlying the passage of amended section 6308(b) is the justification that the "dangers of drunk driving" and the safety hazards they create are sufficient to warrant a lower standard. ${ }^{171}$ While this may be true, this policy logically applies only to automobile stops where the justification for the stop is a perceived violation of the DUI provision of the Motor Vehicle Code. Otherwise, the legislative intent behind the statute would be to lower the standard that applies to all automobile stops, regardless of their nature, in order to ease the prosecution of DUI violators. This objective presumes the constitutional validity of a pretextual stop. Although Whren disposes of the possibility of federal constitutional attacks on pretextual automobile stops where there is probable cause, ${ }^{172}$ such attacks under article I, section 8 are more credible. Moreover, the commonwealth's interest in preventing the dangers posed by drunk drivers cannot, without more, be enough to justify the intrusion involved here. As the court stated in Matos:

The seriousness of criminal activity under investigation, whether it is the sale of drugs or the commission of a violent crime, can never be used as justification for ignoring or abandoning the constitutional right of every individual in this Commonwealth to be free from intrusions upon his or her personal liberty absent probable cause. ${ }^{173}$

Given the express privacy interest implicated in article I, section 8 , the breadth of offenses that this provision of the Motor Vehicle Code covers, and the inherently pretextual nature of the justification for lowering the standard, the legislature is misguided in its blind assertion that the seriousness of alcoholrelated traffic dangers justifies its enactment of section 6308(b).

At least two additional significant policy interests weigh against the constitutionality of section 6308(b). The first concerns the inherently pretexutal nature of traffic stops. At the federal level, the Supreme Court held in Whren that the motivations of the police officer upon performing a traffic stop do not matter as long as probable cause is objectively present. ${ }^{174}$ In its holding, the Court emphasized that the Fourth Amendment only requires probable cause, and that no interest-balancing is necessary as long as probable cause exists and the conduct of the officer during the search and seizure is not

171. See supra note 166

172. Whren, 517 U.S. at 813 ("We think these cases foreclose any argument that the constitutional reasonableness of traffic stops depends on the actual motivations of the individual officers involved.").

173. Commonwealth v. Matos, 672 A.2d 769, 776 (Pa. 1996).

174. Whren, 517 U.S. at 818. 
extraordinary or extreme. ${ }^{175}$ The Court noted that " $[\mathrm{t}]$ he making of a traffic stop ... does not remotely qualify as such an extreme practice, and so is governed by the usual rule that probable cause to believe the law has been broken 'outbalances' private interest in avoiding police contact."176 The conclusion here is not surprising, particularly given the fact that the Supreme Court has never found an explicit privacy interest directly implicated by the Fourth Amendment. Still, even though a pretexutal purpose for the stop will be upheld, probable cause remains the standard.

As I have noted above, the Supreme Court of Pennsylvania has consistently interpreted article I, section 8 to embody an individual privacy right, and stated that the privacy interests of Pennsylvania citizens do in fact outweigh the need for police officers to be able to make traffic stops at whim. Especially in cases of suspected DUI, reasonable suspicion of a drunk driving violation may indeed be enough to warrant a stop. An arbitrary lowering of the standard to allow the police to seize a driver based on any perceived, or probably perceived, traffic violation does nothing to enhance the safety of the roads of the commonwealth. It does, however, infringe on a right that has been recognized in Pennsylvania since a time predating the Fourth Amendment itself. Furthermore, the problem at the state level now goes beyond the situation in Whren. Pretext in Whren was acceptable because probable cause was first acquired by the police officer. ${ }^{177}$ Now, relying on section 6308(b), a police officer in Pennsylvania can have a wholly pretexutal purpose for stopping a driver on less than probable cause. The risk of pretext is far greater than even that afforded by the federal standard-a counterintuitive result given the fact that article I, section 8 unquestioningly affords the citizens of Pennsylvania greater protection than the Fourth Amendment. This is a precarious situation, to say the least. ${ }^{178}$

175. $I d$.

176. $I d$.

177. See Whren, 517 U.S. at 819.

178. One scholar, in commenting on the dangers of the Whren standard, has emphasized:

Once the police possess probable cause that a traffic violation has occurred they have the unfettered discretion of whether to stop the motorist, to issue a summons or arrest the suspected traffic offender, what ticket or tickets to issue, and will enjoy a virtual guarantee of conviction in court. Because the outcome of the criminal or quasi-criminal process in a traffic case begins and the final outcome of the case is de facto determined during the stop itself, it is clear that the law governing the traffic stop is the only law material to the case. In essence, when the police stop a motorist and issue a summons, any subsequent activity in court is merely a "fiction," a process that has no meaning other then [sic] the process itself, as the actual outcome of the case was decided at the conclusion of the traffic stop.

Illya Lichtenberg, Police Discretion and Traffic Enforcement: A Government of Men?, 50 CLEv. ST. L. 
Several scholars have pointed out the dangers of pretextual stops, particularly since the decision in Whren. ${ }^{179}$ A preeminent danger stems from the sheer number of pretextual stops performed daily by law enforcement. Because traffic encounters with police officers occur often, one author has noted that confidence in the law enforcement system is at risk when the stops are arbitrary and without rational explanation. ${ }^{180}$ Moreover, another author has argued that the decision in Whren, with its reliance on a purely objective standard regulating police officers' discretion, virtually signaled the death of Terry: "When we allow the police carte blanche authority to use minor traffic violations as a pretext to stop an individual to search for evidence to support reasonable suspicion of a more serious crime, we nullify Terry's first prong." ${ }^{181}$ The author also pointed out a distinction that state courts in particular have failed to make for quite some time - the distinction between a traffic stop and an investigative detention. ${ }^{182}$ While they may look identical at the outset (and most courts have stopped here), the searches that they validate are drastically different. Thus, the justification of an "investigative detention" standard for traffic stops does not make sense, especially when the "reasonable suspicion" supporting the stop is subterfuge.

Because of the pretext problem, some scholars have encouraged state courts to form their own pretext doctrines, especially if they are permitted to independently construe their own state constitutional provisions. ${ }^{183}$

REv. 425, 428 (2002-03) (footnotes omitted).

179. See, e.g., Peter Shakow, Note, Let He Who Never Has Turned Without Signaling Cast the First Stone: An Analysis of Whren v. United States, 24 Am. J. CRIM. L. 627, 643 (1997); Janet Koven Levit, Pretextual Traffic Stops: United States v. Whren and the Death of Terry v. Ohio, 28 Loy. U. CHI. L.J. 145, 187 (1996).

180. Shakow, supra note 179 , at 643 . The author points out:

The police must be able to articulate a legitimate rationale for the stop if it is adequately questioned, for the practical purpose of unburdening innocent motorists, and, more broadly, to avoid undermining societal confidence in our law enforcement personnel and our legal system.

Such confidence erodes quickly when unequal enforcement is rule, not the exception.

Id.

181. Levit, supra note 179 , at 187.

182. Id. at 186. The author notes:

This Article examines automobile stops. In that context, both investigative impulses and impulses to enforce traffic laws play out in identical ways - stopping (seizing) an automobile and its passengers. This complete congruity makes the stop virtually impossible to parse. Thus, on a blank slate, the most promising resolution to the pretext problem lies at a point beyond the initial stop, during any subsequent search or seizure that may follow the stop, where the distinctness of the investigative stop and the traffic stop may again manifest itself.

Id.

183. See, e.g., Patricia Leary \& Stephanie Rae Williams, Toward a State Constitutional Check on Police Discretion to Patrol the Fourth Amendment's Outer Frontier: A Subjective Test for Pretextual 
Washington has been the leading state to undertake an independent state analysis of its own search and seizure doctrine. In State v. Ladson, ${ }^{184}$ the Washington Supreme Court decided whether pretextual traffic stops violate article I, section 7 of the Washington Constitution, that state's analogue to the Fourth Amendment. The court held that Washington's constitutional provision affords broader protection than the Fourth Amendment and provides Washington citizens a "right to privacy with no express limitations."185 Furthermore, the court noted that Washington does not engage in the same kind of interest-balancing that is undertaken by the United States Supreme Court. ${ }^{186}$ Article I, section 7 of the Washington Constitution prohibits police from making stops without the appropriate "authority of law." 187 The court in Ladson concluded that pretextual traffic stops violate that provision because they constitute seizures without the authority of law provided by a warrant. ${ }^{188}$

One portion of the court's opinion in Ladson is particularly significant here. The dissent in the case argued that the "authority of law" required by the constitution could be provided by statute. ${ }^{189}$ Washington has a statute, one very similar to section $6308(\mathrm{~b})$, giving authority to police officers to make traffic stops and issue traffic citations. ${ }^{190}$ Because the dissent believed that the statute was sufficient to provide the requisite authority of law, it concluded that article I, section 7 of the Washington Constitution did not take pretext into account when assessing the constitutionality of a traffic stop. ${ }^{191}$ The majority responded:

"[C]ases from the earliest days of statehood indicate search warrants were issued pursuant to statutory authorization." That is to say, "statutory authorization" references a statute authorizing a court to issue a warrant, not a statute dispensing with the warrant requirement. Except in the rarest of circumstances, the "authority of law" required to justify a search pursuant to article I, section 7 consists of a valid search warrant or subpoena issued by a neutral magistrate. This court has never

Seizures, 69 Temp. L. Rev. 1007 (1996). The authors developed a proposed quasi-subjective test for use by state courts.

184. 979 P.2d 833 (Wash. 1999).

185. Id. at 837 .

186. Id. The court concluded that the state constitutional provision "holds the line by pegging the constitutional standard to "those privacy interests which citizens of this state have held, and should be entitled to hold, safe from governmental trespass absent a warrant." ' Id. (quoting State v. Myrick, 688 P.2d 151, 154 (Wash. 1984)).

187. WASH. CONST., art. I, § 7.

188. Ladson, 979 P.2d at 842.

189. Id. at 843 (Madsen, J., dissenting).

190. Wash. Rev. Code $\S 46.64 .015$ (2006).

191. Ladson, 979 P.2d at 843 (Madsen, J., dissenting). 
found that a statute requiring a procedure less than a search warrant or subpoena constitutes "authority of law" justifying an intrusion into the "private affairs" of its citizens. This defies the very nature of our constitutional scheme and would set a precedent of legislative deference that I am unwilling to accept in our state's constitutional jurisprudence. It is the court, not the Legislature, that determines the scope of our constitutional protections. ${ }^{192}$

Thus, the court, in refusing to recognize the legislature's authority to create exceptions to Washington's warrant requirement, held that the sufficiency of the "authority of law" validating seizures performed pursuant to statutory grants of authority are to be assessed by the court, not the legislature.

The situation in Pennsylvania is similar. The superior court, especially in Sands, determined that the constitutional standards previously announced by the state supreme court were no longer applicable because they were analyzed under the pre-amendment statutory provisions. What the state of Washington recognized in Ladson, and Pennsylvania should recognize here, is that the reasonableness requirement for police seizures of individuals predates any granting of statutory authority by the state legislature. The warrant requirement in Pennsylvania not only predates any version of section 6308(b), but it predates the Fourth Amendment itself. Ladson is therefore relevant to the inquiry here in two ways. First, it shows that other states which similarly interpret their constitutional provisions to afford greater protections than their federal counterparts have not followed Whren specifically because of the dangers that pretext presents. ${ }^{193}$ Second, it reiterates the proposition that the court — not the legislature- - determines the standards governing rights embodied in the state constitution.

\section{CONCLUSION}

There is perhaps no other area of constitutional jurisprudence that is more confused than that dealing with the semantic (or, arguably, very real) differences between the probable cause and reasonable suspicion standards governing seizures of individuals by police officers. Particularly in traffic stop cases, the narrow Terry standard requiring reasonable suspicion has been quickly and haphazardly applied without much consideration of the doctrinal or policy problems associated with these stops. The Pennsylvania Legislature

192. Id. at 839 n.3 (quoting City of Seattle v. McCready, 868 P.2d 134 (Wash. 1994) and In re Personal Restraint of Maxfield, 945 P.2d 196, 202-203 (Wash. 1997) (Madsen, J., concurring)).

193. Texas and Wyoming have also made similar conclusions to those in Ladson. See Leary \& Williams, supra note 183, at 1026-27. 
has not escaped the confusion. In amending section 6308(b), it has fallen prey to the misguided notion that the probable cause standard established in Pennsylvania is relatively new and malleable. However, upon closer examination, it is emphatically the case that the probable cause requirement to make traffic stops in Pennsylvania is a matter of constitutional law that cannot be altered by legislative whim. The location of the DUI statute in the Motor Vehicle Code presents clear problems when trying to decipher what standard should govern stops made for suspected violations. A Terry-type standard makes some - even good - sense in these situations as the "criminal activity" going on is of a more serious sort than a minor traffic infraction. However, as it is included in the Motor Vehicle Code, stops are subject to the Supreme Court of Pennsylvania's probable cause standard.

The legislature's discontent with the Pennsylvania Supreme Court's "double standard" is thus self-created and cannot be remedied by a simple amendment to section 6308(b) which, like every other statue on the books in the Commonwealth, is subject to constitutional scrutiny. What we inevitably end up with in section 6308(b), then, is a lower standard, perhaps even lower than the federal standard; that is inherently pretextual; that invades the independent right of privacy recognized under article I, section 8 of the Pennsylvania Constitution; and that does nothing but confuse both the letter and spirit of constitutional criminal procedure law. And what is more, it does so in furtherance of not a single colorable state policy. The Supreme Court of Pennsylvania will hopefully get the opportunity to once and for all settle the law in this area and create an example for other states to follow. In doing so, it can reassure the citizens of Pennsylvania that the rights of privacy and protection embodied in article I, section 8 do in fact extend beyond their own driveways. 